\title{
Effect of diet-induced negative energy balance on the feeding behavior of dairy cows
}

\author{
S. M. Moore and T. J. DeVries* (1) \\ Department of Animal Biosciences, University of Guelph, 50 Stone Rd. East, Guelph, ON, N1G 2W1, Canada
}

\begin{abstract}
The objective of this study was to determine how feeding behavior of dairy cows is altered in response to dietinduced negative energy balance, and if this response varies depending on dietary particle size distribution. Multiparous Holstein cows $(\mathrm{n}=30$; days in milk $=59$ \pm 5 ; parity $=2.8 \pm 0.19$ ), producing $44.6 \pm 1.2 \mathrm{~kg} / \mathrm{d}$ of milk, were fed (on a dry matter basis) a lactating diet [net energy of lactation $\left(\mathrm{NE}_{\mathrm{L}}\right)=1.66 \mathrm{Mcal} / \mathrm{kg} ; 68 \%$ forage, including $1.8 \%$ wheat straw] during a 2 -wk baseline period. To induce negative energy balance, cows were then exposed for 3 wk to 1 of 2 diets formulated for a $20 \%$ reduction in energy available for milk $\left(\mathrm{NE}_{\mathrm{L}}=1.58\right.$ $\mathrm{Mcal} / \mathrm{kg} ; 73 \%$ forage, including $17.2 \%$ wheat straw). These diets were identical, only varying in straw chop length: (1) long straw diet (LS): straw chopped with a $10.2-\mathrm{cm}$ screen, or (2) short straw diet (SS): straw chopped with a 2.54-cm screen. Cows consumed $25.6 \pm$ $0.26 \mathrm{~kg} / \mathrm{d}$ during the baseline period. Dry matter intake decreased on the experimental diets; dry matter intake was greater for the SS diet as compared with the LS diet $(23.1$ vs. $22.5 \mathrm{~kg} / \mathrm{d}$; standard error $=0.47)$. During the baseline period, cow serum nonesterified fatty acids (NEFA) and blood $\beta$-hydroxybutyrate averaged 0.27 \pm 0.02 and $0.71 \pm 0.05 \mathrm{mmol} / \mathrm{L}$, respectively. During the experimental period, NEFA and $\beta$-hydroxybutyrate averaged 0.34 and $1.04 \mathrm{mmol} / \mathrm{L}$, respectively, with a peak of NEFA $(0.63 \pm 0.06 \mathrm{mmol} / \mathrm{L})$ occurring $4 \mathrm{~d}$ after dietary change. During baseline, cows produced $42.3 \pm 0.33 \mathrm{~kg} / \mathrm{d}$ of milk; milk yield was decreased for both SS cows and LS cows during the experimental period $(\mathrm{SS}=39.0, \mathrm{LS}=37.8 \mathrm{~kg} / \mathrm{d}$; standard error $=0.67)$. On the experimental diets, cows spent more time eating (266.8 vs. $221.8 \mathrm{~min} / \mathrm{d}$ ), had longer meal lengths (46.9 vs. $37.5 \mathrm{~min} / \mathrm{meal}$ ), and consumed fewer meals (7.1 vs. 7.7 meals/d) compared with the baseline period. Within the experimental period, LS cows spent more time eating per day than SS cows $(\mathrm{LS}=281.3$,
\end{abstract}

Received October 4, 2019.

Accepted March 25, 2020.

*Corresponding author: tdevries@uoguelph.ca
$\mathrm{SS}=252.2 \mathrm{~min} / \mathrm{d})$. During the baseline period cows sorted against long particles $(>19 \mathrm{~mm})$, did not sort medium particles ( 8 to $19 \mathrm{~mm}$ ), and sorted for short (4 to $8 \mathrm{~mm})$ and fine $(<4 \mathrm{~mm})$ particles. Cows did not change sorting of long particles on the SS diet, but increased sorting against these on the LS diet. On the SS diet cows did not change their sorting of short and fine particles. On the LS diet cows increased sorting for short and fine particles. In the baseline period, no association was detected between feed sorting and serum NEFA concentration. During the experimental period, greater NEFA concentration was associated with greater sorting in favor of short particles for both the LS and SS diets. Furthermore, greater NEFA concentration was associated with greater sorting against the longest particles for both the LS and SS diets. No associations of blood and meal variables were detected during the experimental period. Overall, cows altered their feed sorting behavior in response to experiencing a diet-induced period of negative energy balance and the severity of negative energy balance was associated with the extent of that change in feed sorting.

Key words: negative energy balance, sorting, behavior

\section{INTRODUCTION}

Dairy cows must rely heavily on their current and past intake of nutrients to support the demands of lactation (van Hoeij et al., 2017). In the first weeks of lactation, dairy cows often do not consume sufficient DMI to meet their nutrient requirements, leading to negative energy balance (NEB). This occurs as the amount of energy required for maintenance of milk production exceeds the amount of energy the cow can obtain through dietary sources, and as a result, the cow will start to mobilize body fat as a source of energy (Goff and Horst, 1997). Consequently, many dairy cows may experience hyperketonemia in early lactation $(43 \%$; McArt et al., 2012). This prevalent condition within the dairy industry is associated with losses in milk production (McArt et al., 2012), poor reproductive performance (Walsh et al., 2007), and increased risks of other health disorders throughout lactation (Suthar et al., 2013). Despite the 
pervasiveness of hyperketonemia, limited research is available on how dairy cows may alter their feeding behavior in response to the experience of NEB.

Evidence indicates that cows may alter their feeding behavior, including feed sorting and meal parameters, when faced with metabolic changes or physiological demands. For example, researchers have demonstrated that dairy cows will alter their TMR sorting behavior in response to a period of low rumen $\mathrm{pH}$, selecting in favor of the long fibrous particles in an attempt to ameliorate the effects of low rumen $\mathrm{pH}$ (Beauchemin and Yang, 2005; DeVries et al., 2008). DeVries et al. (2011) provided some preliminary evidence that at a single point in time, cows experiencing some level of NEB preferentially selected their diet to increase their total nutrient intake. Additionally, Tolkamp et al. (1998) demonstrated that early-lactation dairy cows, given a choice of high and low protein feeds, consumed more protein than predicted at random. Furthermore, Azizi et al. (2009) reported that cows with greater milk yields (and therefore facing greater energy demands) consumed larger meals, to consume more DM each day, than cows producing lesser amounts of milk. Similarly, it has been demonstrated that dairy cows will increase their meal frequency and meal length from early to peak lactation as nutrient requirements increase (DeVries et al., 2003). It is, however, unknown if dairy cows will modify their dietary selection in response to an induced period of NEB, and whether cows will alter meal size and frequency in attempt to meet their nutrient requirements during such a time period.

The objective of this study was to determine how dairy cow feeding behavior, including diet selection (feed sorting) and meal parameters (meal size, length, frequency), is altered in response to a diet-induced period of NEB. Given that feed sorting (Miller-Cushon and DeVries, 2017) and time spent eating per meal (Grant and Ferraretto, 2018) are enhanced when dairy cows are fed diets with longer forage particle size, we also aimed to determine how this response to a diet-induced period of NEB may vary depending on dietary particle size distribution. It was hypothesized that cows exposed to a diet that does not meet their nutrient requirements for production would alter their feeding behavior to maximize nutrient consumption, particularly when fed a diet that is more easily sorted (i.e., a diet with longer straw particle size).

\section{MATERIALS AND METHODS}

\section{Animals and Housing}

Thirty multiparous (average parity $=2.8 \pm 0.19$; mean $\pm \mathrm{SD}$ ), nonpregnant lactating Holstein dairy cows were selected from the University of Guelph, Elora Research Station-Dairy Facility (Elora, ON, Canada) herd and enrolled in the study. Selected individuals, at entry to the study, averaged $59 \pm 5$ DIM, BW of 726 $\pm 57.3 \mathrm{~kg}$, BCS of $3.0 \pm 0.3$, and produced $44.6 \pm 1.2$ $\mathrm{kg} / \mathrm{d}$ of milk. Before study enrollment, the health status of each cow was evaluated and cows having experienced serious health concerns during the transition period or early lactation (compromising their ability to peak in production) were excluded from the study.

Cows were tested in 2 groups of 15 cows, over time, with treatments replicated in the same pen. Cows in each group had access to 15 automated feed bins, 15 lying stalls, 1 cow brush, and 2 water troughs at each end of the pen, which offered ad libitum access to water. The freestalls were laid out in 2 rows of 15; however, half of the stalls were roped off to ensure that each group of 15 had access to only 15 pens and was at $100 \%$ stocking density. Stalls were $295 \mathrm{~cm}$ in total length and $127 \mathrm{~cm}$ wide, with a neck rail positioned $188 \mathrm{~cm}$ from the back of the stall and $125 \mathrm{~cm}$ above the stall base. The base of the free stalls were mattresses (Pasture Mat; ProMat, Woodstock, ON, Canada) that were bedded with chopped straw $(1 \times /$ wk $)$ and groomed $2 \times / d$. Alleys were cleaned with an automatic manure scraper that removed manure every $2 \mathrm{~h}$ for a total of $12 \times / \mathrm{d}$. The cows were individually assigned (and trained) to eat from an individual automated feed bin (Insentec, B.V., Marknesse, the Netherlands). Cows were trained to access their assigned feed bin $3 \mathrm{~d}$ before the beginning of the study. Cows were milked twice a day at 0500 and $1700 \mathrm{~h}$ in a rotary parlor (DeLaval International AB, Tumba, Sweden).

The use of cows and experimental procedures complied with the guidelines of the Canadian Council on Animal Care (CCAC, 2009) and were approved by the University of Guelph Animal Care Committee (AUP \#3245).

\section{Experimental Design}

Sample size and power analyses were used to calculate (as per Morris, 1999) the minimum number of replicates needed per treatment $(n=15)$ to detect a $10 \%$ level of observed mean difference for the primary outcome variables, including blood metabolites, DMI, feed sorting, and milk production. Estimates of variation for these variables were based on previously reported values (DeVries et al., 2007; DeVries and Gill, 2012). Each group of 15 cows was exposed to the same 7-wk experimental protocol, consisting of 3 observation periods. The first was a baseline period in which all cows were fed a standard lactating cow TMR (Table 1), balanced for $45 \mathrm{~kg} / \mathrm{d}$ of milk (NRC, 2001), and observed 
for $14 \mathrm{~d}$. Before this baseline period, all cows were fed that same diet since the beginning of their respective lactations. Cows were then exposed to 1 of 2 treatment TMR diets for a period of $21 \mathrm{~d}$. Treatment diets (Table 1) were formulated for a $20 \%$ reduction in energy available for milk production to induce NEB, based on previous research by Perkins et al. (2002) and Ferraretto et al. (2014). Treatment diets contained either (1) straw chopped with a $2.54-\mathrm{cm}$ screen $(\mathbf{S S} ; \mathrm{n}=15)$ or $(2)$ straw chopped with a $10.16-\mathrm{cm}$ screen $(\mathbf{L S} ; \mathrm{n}=15)$. These diets were identical, only varying in the length of the straw particle size, which was chopped using a bale processor (Haybuster Model H-1150, Jamestown, ND). Diet assignment was balanced, within group, for parity, DIM, and production level. Treatments were assigned to alternating feed bins, leaving the LS and SS treatments adjacent to each other, to minimize synchronization of feeding behavior (King et al., 2016). In the first experimental group of 15 cows, 8 cows were on the LS treatment and 7 were on the SS, whereas in the second group of 15 cows, 8 cows were on the SS treatment and 7 were on the LS treatment. Following the 21-d experimental period, cows were placed back onto the baseline diet and followed for an additional $14 \mathrm{~d}$. Across all days of the study, cows were fed for approximately $10 \%$ refusals to ensure samples were available to assess feed sorting. Each day, the base diet, without straw, was prepared using a TMR mixer (Jaylor model 5572, Jaylor Fabricating, Orton, ON, Canada). Feed was then transferred to a feed cart (Super Data Ranger, American Calan, Northwood, NH) and the appropriate amount of straw was added and mixed for 3 to $5 \mathrm{~min}$ before delivery. Diets were prepped and delivered to the cows once a day at approximately $1400 \mathrm{~h}$. The bins were cleaned out every day at $1300 \mathrm{~h}$ before fresh feed delivery.

\section{Measuring Cow Behavior}

Feeding behavior and DMI were monitored using the automated feed bins, as validated by Chapinal et al. (2007). From the recorded data, the duration of each visit to the feed bin, the amount of feed consumed (start weight - end weight) during each visit, and the rate of consumption for each visit were calculated. These data were then summarized to calculate daily DMI $(\mathrm{kg} / \mathrm{d})$, daily time spent feeding $(\mathrm{min} / \mathrm{d})$, and average feeding rate $(\mathrm{kg} / \mathrm{min})$. Individual feeding bouts were combined and separated into meals using a meal criterion (i.e., the minimum duration of time between meals) calculated for each cow. Meal criteria were calculated for each cow and for each period using methods described by DeVries et al. (2003); a software package (MIX 3.1.3; MacDonald and Green, 1988) was used
Table 1. Ingredient and chemical composition (mean $\pm \mathrm{SD}$ ) of the lactating cow and treatment TMR

\begin{tabular}{|c|c|c|}
\hline Composition & $\begin{array}{c}\text { Control } \\
\text { diet }\end{array}$ & $\begin{array}{c}\text { Experimental } \\
\operatorname{diets}^{1}\end{array}$ \\
\hline \multicolumn{3}{|l|}{ Ingredient, $\%$ of DM } \\
\hline Corn silage $^{2}$ & 33.0 & 27.8 \\
\hline Wheat straw ${ }^{3}$ & 1.8 & 17.2 \\
\hline Alfalfa haylage ${ }^{4}$ & 33.1 & 28.0 \\
\hline High-moisture corn ${ }^{5}$ & 19.1 & 16.1 \\
\hline Lactating cow supplement ${ }^{6}$ & 13.0 & 10.9 \\
\hline \multicolumn{3}{|l|}{ Chemical composition ${ }^{7}$} \\
\hline $\mathrm{DM}, \%$ & $42.9 \pm 2.03$ & $48.3 \pm 3.71$ \\
\hline $\mathrm{CP}, \%$ of $\mathrm{DM}$ & $14.7 \pm 3.02$ & $12.8 \pm 2.11$ \\
\hline $\mathrm{ADF}, \%$ of $\mathrm{DM}$ & $20.6 \pm 6.15$ & $25.5 \pm 5.13$ \\
\hline $\mathrm{NDF}, \%$ of $\mathrm{DM}$ & $31.1 \pm 7.36$ & $37.6 \pm 6.17$ \\
\hline TDN, $\%$ of DM & $72.8 \pm 4.79$ & $69.1 \pm 4.00$ \\
\hline Starch \% of DM & $28.5 \pm 7.70$ & $25.1 \pm 7.89$ \\
\hline Ash \% of DM & $6.9 \pm 0.75$ & $6.7 \pm 0.50$ \\
\hline $\mathrm{Ca}, \%$ of $\mathrm{DM}$ & $0.9 \pm 0.18$ & $0.9 \pm 0.19$ \\
\hline P. $\%$ of DM & $0.4 \pm 0.05$ & $0.4 \pm 0.06$ \\
\hline $\mathrm{NE}_{\mathrm{L}}, \mathrm{Mcal} / \mathrm{kg}$ of $\mathrm{DM}$ & $1.66 \pm 0.12$ & $1.58 \pm 0.09$ \\
\hline
\end{tabular}

${ }^{1}$ Experimental diets were identical in composition, with the exception of the chop length of the included straw: LS = long straw diet (straw chopped with a 10.16 -cm screen); SS = short straw diet (straw chopped with a $2.54-\mathrm{cm}$ screen). Treatment diets were fed over a 21-d period, beginning at the start of $\mathrm{d} 14$ to the end of $\mathrm{d} 35$.

${ }^{2}$ Corn silage had a DM of $31.5 \pm 6.03 \%$ and chemical composition (DM basis) $8.2 \pm 0.42 \% \mathrm{CP}, 18.1 \pm 0.88 \% \mathrm{ADF}, 29.9 \pm 2.83 \% \mathrm{NDF}$, and $33.9 \pm 0.43 \%$ starch.

${ }^{3}$ Straw had a DM of $92.2 \pm 1.19 \%$ and chemical composition (DM basis) $2.5 \pm 0.28 \% \mathrm{CP}, 54.0 \pm 2.60 \% \mathrm{ADF}$, and $80.3 \pm 0.99 \% \mathrm{NDF}$.

${ }^{4}$ Alfalfa haylage had a DM of $36.2 \pm 0.87 \%$ and chemical composition (DM basis) $15.8 \pm 1.56 \% \mathrm{CP}, 35.0 \pm 3.56 \% \mathrm{ADF}$, and $44.4 \pm 5.4 \%$ NDF.

${ }^{5}$ High-moisture corn had a DM of $75.1 \pm 0.43 \%$ and chemical composition (DM basis) $7.4 \pm 0.18 \% \mathrm{CP}, 61.1 \pm 0.13 \%$ starch, $2.9 \pm 0.46 \%$ $\mathrm{ADF}$, and $7.7 \pm 0.13 \% \mathrm{NDF}$.

${ }^{6}$ Supplied by Floradale Feed Mill Ltd. (Floradale, Ontario, Canada) including ingredients (as is); $34.0 \%$ SoyPlus (Landus Cooperative, Ames, IA), $18.0 \%$ soy hulls (ground), $17 \%$ canola, $13.6 \%$ wheat shorts, 8.5\% soybean meal, 2\% Diamond V Yeast XP (Diamond V, Cedar Rapids, IA), $1.9 \%$ limestone calcium carbonate, $1.3 \%$ magnesium oxide, $1.0 \%$ vitamin E, $1.0 \%$ fine salt, $1.0 \%$ tallow, $0.5 \%$ Floradale Feed Mill Organic Ruminant Micro Premix (Floradale Feed Mill Ltd., ON, Canada), 0.07\% Alkosel 2000 (Lallemand Animal Nutrition, Montreal, QC, Canada), 0.05\% Rumensin (Elanco, Greenfield, IN), and 0.01\% Rovimix H-2 Biotin 20000 (DSM, Herleen, the Netherlands).

${ }^{7}$ Values were obtained from chemical analysis of TMR samples. $\mathrm{NE}_{\mathrm{L}}$ was calculated based on NRC (2001) equations.

to fit normal distributions to the frequency of $\log _{10^{-}}$ transformed intervals of time between feeding visits. In regard to meal parameters, meal frequency (no./d) was determined for each cow by summarizing the number of intervals between feeding events that exceeded their meal criterion. Meal length (min/meal) was calculated as the time between the start of the first feeding bout, until the end of the last bout at which time the meal criterion was exceeded. Meal size ( $\mathrm{kg}$ of $\mathrm{DM} /$ meal) was calculated as DMI divided by meal frequency.

As validated by Schirmann et al. (2009), an electronic monitoring system (HR-TAG-LD, SCR Engineers Ltd., 
Netanya, Israel) was used to monitor rumination activity. A rumination data logger attached to a nylon collar was fitted to each cow on the day of enrollment. Rumination activity was monitored $24 \mathrm{~h} / \mathrm{d}$ for the 7 -wk period. These data, stored in 2-h intervals, were used to determine total time spent ruminating throughout each day.

\section{Feed Sampling and Analysis}

Two samples of fresh feed from the lactating cow diets were collected $3 \mathrm{~d} / \mathrm{wk}$ (Sunday, Tuesday, Thursday) at feed delivery time to determine $\mathrm{DM} /$ nutrient composition and sorting, respectively, throughout the duration of the study. One refusal sample, of approximately $500 \mathrm{~g}$ (as-fed), was collected from each bin of each cow $3 \times /$ wk (Monday, Wednesday, Friday) to determine feed sorting. Before feed refusal collection, the remaining feed contents of each bin were mixed together and homogenized to generate a representative sample. Component samples of the TMR ingredients were also collected every 3 wk for DM, nutrient composition, and particle size determination (Table 2). All samples were frozen upon collection at $-15^{\circ} \mathrm{C}$ for further analysis. Before analysis, all samples were thawed in a refrigerator for at least $24 \mathrm{~h}$.

All feed samples collected for DM and nutrient analyses were then oven-dried at $55^{\circ} \mathrm{C}$ for $48 \mathrm{~h}$ for $\mathrm{DM}$ analysis. Fresh and refused feed, and TMR component samples collected for particle size analysis were processed using a 4-screen Penn State Particle Separator
(PSPS; Heinrichs, 2013; Maulfair and Heinrichs, 2013), which separated the sample into 4 fractions based on particle size: long $(>19 \mathrm{~mm})$, medium $(<19,>8 \mathrm{~mm})$, short $(<8,>4 \mathrm{~mm})$, and fine $(<4 \mathrm{~mm})$. After being separated into fractions, PSPS samples were oven-dried at $55^{\circ} \mathrm{C}$ for $48 \mathrm{~h}$.

The sorting of each PSPS fraction was calculated (per Leonardi and Armentano, 2003) by dividing the actual amount of feed consumed of each fraction by the predicted amount of feed consumed of that fraction and expressing it as a percentage. For each fraction, the actual amount consumed was calculated by subtracting the DM refused from the DM offered, as determined by the PSPS analysis. The predicted amount consumed for each fraction was calculated as the product of the DMI of the total diet multiplied by the DM percentage of that fraction in the fed TMR. If the sorting value equaled $100 \%$, then no sorting of the particle fraction occurred; a value $<100 \%$ indicated sorting against that particle size fraction, whereas a value $>100 \%$ indicated sorting in favor of that particle fraction.

All fresh PSPS and DM samples were then ground through a 1-mm screen (Model 4 Wiley Laboratory Mill, Thomas Scientific, Swedesboro, NJ). Ground samples, pooled by week, were then sent to A \& L Canadian Laboratories Inc. (London, ON, Canada) for analysis of $\mathrm{DM}\left(135^{\circ} \mathrm{C}\right.$; AOAC International, 2000: method 930.15), ash $\left(535^{\circ} \mathrm{C}\right.$; AOAC International, 2000: method 942.05), ADF (AOAC International, 2000: method 973.18), NDF with heat-stable $\alpha$-amylase and sodium sulfite (Van Soest et al., 1991), CP (N ×

Table 2. Particle size distribution ${ }^{1}$ (mean $\pm \mathrm{SD}$ ), and nutrient content (mean $\pm \mathrm{SD}$ ) by particle size of the fresh control and experimental $\operatorname{diets}^{2}$

\begin{tabular}{lccc}
\hline Item & Control diet & LS & SS \\
\hline \% of DM & & & \\
Long & $12.6 \pm 6.11$ & $21.1 \pm 4.68$ & $12.7 \pm 2.93$ \\
Medium & $45.7 \pm 5.11$ & $38.8 \pm 2.54$ & $45.0 \pm 2.35$ \\
Short & $15.9 \pm 1.32$ & $14.8 \pm 1.23$ & $16.8 \pm 1.38$ \\
Fine & $25.8 \pm 3.34$ & $25.3 \pm 3.34$ & $25.5 \pm 2.67$ \\
ADF, ${ }^{3} \%$ of screen DM & $29.0 \pm 1.35$ & $34.2 \pm 0.82$ & $30.0 \pm 1.73$ \\
Long & $24.8 \pm 0.61$ & $29.5 \pm 0.28$ & $28.2 \pm 1.08$ \\
Medium & $16.0 \pm 0.42$ & $20.3 \pm 1.10$ & $22.7 \pm 1.12$ \\
Short & $12.5 \pm 0.59$ & $16.0 \pm 0.39$ & $18.7 \pm 1.45$ \\
Fine & & & \\
NDF, ${ }^{3} \%$ of screen DM & $41.5 \pm 2.28$ & $46.3 \pm 7.64$ & $42.4 \pm 2.71$ \\
$\quad$ Long & $35.2 \pm 0.90$ & $42.6 \pm 0.32$ & $40.6 \pm 1.34$ \\
Medium & $26.6 \pm 0.68$ & $31.8 \pm 0.39$ & $36.5 \pm 2.96$ \\
Short & $20.9 \pm 0.15$ & $24.9 \pm 0.44$ & $29.6 \pm 0.76$ \\
Fine & & \\
\hline
\end{tabular}

${ }^{1}$ Particle size determined by using the Penn State Particle Separator (PSPS) to process feed samples. The PSPS has a long screen of $19 \mathrm{~mm}$, a medium screen of $8 \mathrm{~mm}$, a short screen of $4 \mathrm{~mm}$, and a fine screen of $<4$ $\mathrm{mm}$.

${ }^{2} \mathrm{LS}=$ long straw diet (straw chopped with a 10.16-cm screen); SS = short straw diet (straw chopped with a 2.54-cm screen). Treatment diets were fed over a 21-d period (1.58 Mcal $/ \mathrm{kg}$ of $\mathrm{NE}_{\mathrm{L}} ; 73 \%$ forage), beginning at the start of d 15 to the end of d 35. Control diet (1.66 Mcal/ $\mathrm{kg}$ of $\mathrm{NE}_{\mathrm{L}} ; 68 \%$ forage) was fed from d 1 to 14 .

${ }^{3}$ Values were obtained from chemical analysis of TMR samples separated by particle size with the PSPS. 
6.25; AOAC International, 2000: method 990.03; Leco FP-528 Nitrogen Analyzer, Leco, St. Joseph, MI), and starch (heat-stable amylase and amyloglucosidase; AOAC International, 2000: method 996.11).

\section{Monitoring Health Status, Milk Production, and Components}

Body condition score of all cows was assessed by 1 of 2 people, using the 5 -point scale designed by Wildman et al. (1982), at increments of 0.25. This assessment occurred at the time of enrollment, and throughout the experimental period. To ensure consistent and accurate scoring, inter-rater reliability testing was conducted between 2 individuals, with a resultant $85 \%$ accuracy rate. Cow BW was recorded $2 \times / d$, at each milking, using a scale (DeLaval automatic weigh scale, Tumba, Sweden) placed at the exit of the parlor. Wireless telemetry boluses (eBolus, eCow Ltd., Devon, UK) were used to measure reticulorumen $\mathrm{pH}$ to assess rumen $\mathrm{pH}$ stability (as validated by Falk et al., 2016). At time of enrollment, the boluses were administered orally using a balling gun. Data consisted of reticulorumen $\mathrm{pH}$ data points on 15-min intervals, $24 \mathrm{~h} / \mathrm{d}$, throughout the trial period. Data were downloaded $2 \times /$ wk from each individual cow and amalgamated into a continuous record for each individual cow. Time spent below a $\mathrm{pH}$ threshold of 5.8 was then calculated, along with daily mean, minimum, and maximum $\mathrm{pH}$ values.

A total of 8 blood samples were taken from the coccygeal vein of each enrolled cow at $1200 \mathrm{~h}$, before their fresh feed delivery, and placed into $10-\mathrm{mL}$ red top vacutainer tubes. Samples were taken on d 1 and 8 (baseline) and d 15, 19, 23, 27, 31, and 35 (experimental period). Blood samples were left to sit at room temperature for a period of $1 \mathrm{~h}$ following collection to allow coagulation and facilitate fibrinogen breakdown. After $1 \mathrm{~h}$, samples were centrifuged (Thermo Fisher Scientific Sorvall ST40R, Langenselbold, Germany) at $2,600 \times g$ and $18^{\circ} \mathrm{C}$ to separate cells from serum. For each blood sample, $1.5 \mathrm{~mL}$ of serum was drawn and frozen until the time of analysis. Serum samples were sent to the Animal Health Laboratory, University of Guelph, where they were analyzed for nonesterified fatty acids (NEFA) and glucose as indicators of energy status. Additionally, a Freestyle Precision Neo meter (Abbott Diabetes Care, Saint Laurent, QC, Canada) as validated by Kanz et al. (2015) was used to measure BHB concentrations (mmol/L), cow-side, by placing one drop of blood on a blood ketone test strip.

Milk yield was recorded at every milking in the milking parlor (using Delpro software, DeLaval International AB, Tumba, Sweden). Milk samples were collected from each cow at the time of milking $2 \mathrm{~d} / \mathrm{wk}$
(Wednesday and Thursday). These samples were sent to the DHI testing laboratory (CanWest DHI, Guelph, ON, Canada) for component analysis (fat, protein, MUN, and SCC) using a Fourier Transform Infrared full spectrum analyzer (Milkoscan FT+ and Milkoscan 6000; Foss, Hillerød, Denmark). Milk composition samples were used to determine the yield of $4 \% \mathrm{FCM}$ $(\mathrm{kg} / \mathrm{d})$, calculated as $[0.4 \times$ milk yield $(\mathrm{kg} / \mathrm{d})]+[15.0$ $\times$ fat yield $(\mathrm{kg} / \mathrm{d})]$ (NRC, 2001). Energy-corrected milk was calculated as ECM $(\mathrm{kg} / \mathrm{d})=(0.327 \times \mathrm{kg}$ of milk $)$ $+(12.95 \times \mathrm{kg}$ of fat $)+(7.2 \times \mathrm{kg}$ of protein $)$ (Tyrrell and Reid, 1965).

\section{Statistical Analyses}

All statistical analyses were conducted using SAS 9.4 software (SAS Institute Inc., 2013). Significance was declared at $P \leq 0.05$ and tendencies were reported if $0.05<P \leq 0.10$. If the $P$-value of an interaction term was $\leq 0.05$ it was retained in the model, otherwise interaction terms were disregarded. Before analyses, data were assessed for normality using the UNIVARIATE procedure of SAS. All assumptions of normality were met for the majority of the data, except for SCC, which was normalized using the natural logarithm. Due to the technical failure of 3 boluses, reticulorumen $\mathrm{pH}$ activity was conducted with a sample size of 27 cows (LS, $n=$ $13 ; \mathrm{SS}, \mathrm{n}=14$ ). In situations where the automated feed bins or rumination collars malfunctioned, only days with complete data were included in the analyses.

To address our study hypothesis, comparisons of data were made: (1) between the baseline period and the experimental period, and (2) between the LS and SS treatments within the experimental period. For the first analysis, differences between the experimental and baseline periods were assessed for each variable within treatment. For each cow, their baseline average for feed sorting, feeding behavior, DMI, rumination behavior, reticulorumen $\mathrm{pH}$, and milk production and composition were subtracted from those data for each measurement day during the experimental period. These data were analyzed in mixed-effect linear regression models using the MIXED procedure of SAS, treating day within experimental period as a repeated measure. For each of these models, the dependent variable was the difference in that variable compared with the baseline average. Each model included the fixed effects of day and treatment. The subject of the repeated statement was cow within group, and group was considered random.

Differences between treatments within the experimental period were tested in a secondary analysis. Data on feed sorting, feeding behavior, DMI, rumination behavior, reticulorumen $\mathrm{pH}$, and milk production and composition were summarized by treatment, cow, and 
day. To account for pre-existing variability, the average values of each measure during the baseline period were included as covariates in all models. Data were analyzed similar to the first analysis, using the MIXED procedure of SAS to build mixed-effect linear regression models where day was treated as a repeated measure. Each model included the fixed effects of day and treatment. The subject of the repeated statement was cow within group, and group was considered random.

For all mixed model analyses, compound symmetry, heterogeneous compound symmetry, first-order autoregressive, and heterogeneous first-order autoregressive were selected as covariance structures for the various models, depending on the basis of best fit according to Schwarz's Bayesian information criterion. When day by treatment interactions were detected, the PDIFF procedure in the LSMEANS statement was used to investigate differences by day, using the Tukey-Kramer adjustment.

To determine the occurrence of feed sorting (i.e., difference in sorting values from 100\%), both between the baseline and experimental period within treatment, and between treatments in the experimental period, the summarized data for each particle size were tested for a difference from 100 using $t$-tests, within the previously described models.

To test whether the degree of NEB experienced was associated with the degree to which cows altered their feeding behavior, serum NEFA and BHB data and feeding behavior data (including feed sorting and meal parameters) were summarized by cow and period, and associated within period using the regression procedure of SAS. Univariable models were generated and only those associations that were detected as significant or tendencies are further reported.

\section{RESULTS}

The LS and SS treatments decreased their DMI from the baseline to a similar extent following the exposure to the experimental diets (Table 3). Across treatments, cows also spent more time eating per day on the experimental diets, as compared with the baseline period. The LS cows spent, on average, $20 \mathrm{~min} / \mathrm{d}$ more time eating and ate at a slower rate than SS cows and compared with their baseline period (Table 3 ). No differences in BCS or BW was detected $(P \geq 0.59)$ between the baseline and experimental period or by treatment.

Following the exposure to the experimental diets, particle size treatments increased serum NEFA concentrations, with a peak occurring on d 19 for cows on both the LS and SS treatments (Table 4; Figure 1a). Blood BHB concentration increased similarly (by 0.33 and $0.26 \mathrm{mmol} / \mathrm{L}$, respectively) for both LS and SS

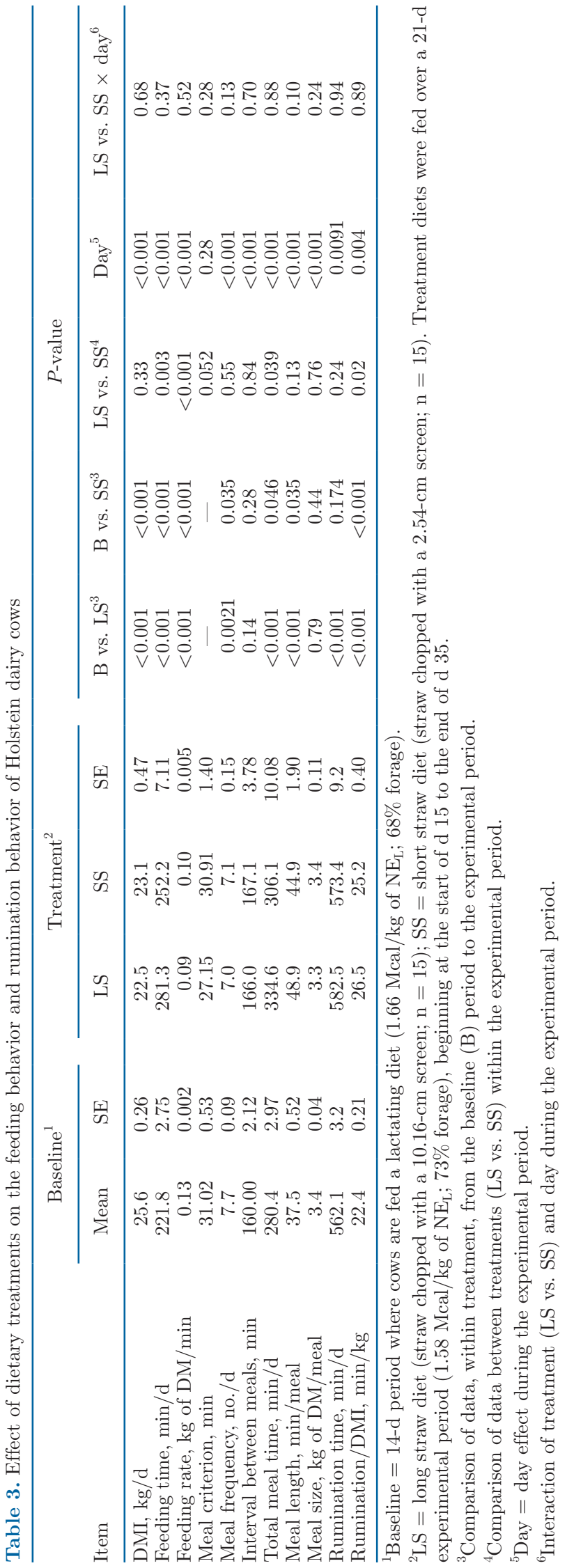


treatments compared with their baseline averages (Table 4, Figure 1b). Furthermore, serum glucose concentration decreased similarly across treatments following the switch from the baseline diet to the experimental diets (Table 4). Reticulorumen $\mathrm{pH}$ remained consistent across periods (Table 5). No treatment effect was detected for reticulorumen $\mathrm{pH}$; however, the range was reduced similarly, across treatments, compared with their average baseline values during the experimental period.

Particle size treatments decreased milk yield similarly when compared with the baseline (Table 6). Fat yield and SCC remained consistent across experimental periods. Both fat and protein content in milk, as well as protein yield and MUN, were different for both LS and SS cows compared with their baseline averages. Milk fat content was reduced for LS cows compared with their baseline values. The SS cows, however, experienced an increase in milk fat content compared with their baseline. Milk protein content decreased for both LS and SS treatments during the experimental period. Similarly, milk protein yield decreased for both treatments during the experimental period. Last, MUN concentration increased similarly for both treatments during the experimental period.

With respect to meal parameters, cows had fewer meals, but spent more time eating per meal across treatments during the experimental period compared with their baseline (Table 3). Within the experimental period, no differences were detected between particle size treatments for meal frequency, interval between meals, meal length, and meal size. Treatment differences were detected for total meal time, with cows on the LS diet spending more time eating their meals per day than SS cows.

Cows on the LS diet spent more time ruminating per day during the experimental period compared with their baseline (Table 3). These cows also ruminated more per kilogram of DM than cows on the SS diet. All cows, across treatments, increased their rumination time per kilogram of DM on the experimental diets.

During the baseline period, all cows sorted against the longest dietary particles, did not sort medium particles, and sorted in favor of the short and fine particles (Table 7). When on the treatment diets, cows on the LS diet increased their sorting against the longest particle fraction, and their sorting in favor of the short and fine particle fractions, whereas no change in sorting was detected for cows on the SS diet. Treatment by day interactions were detected for all dietary particle fractions, regardless of treatment diet. Cows on the LS and SS diets sorted against the longer fractions of the diet on all days except for d 25, 29, and 32, where sorting did not occur for this fraction on either treatment.

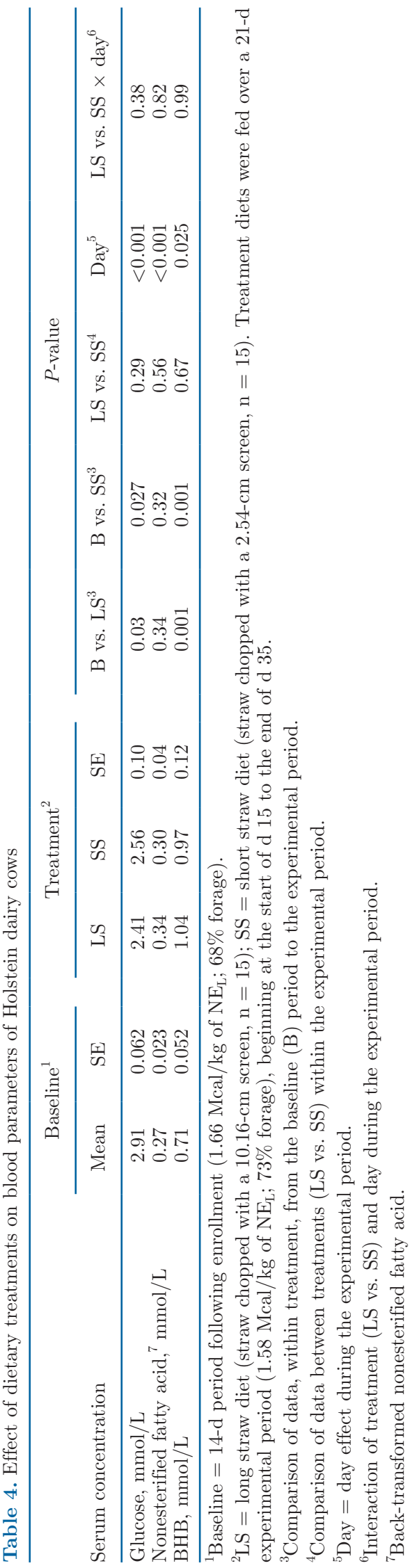



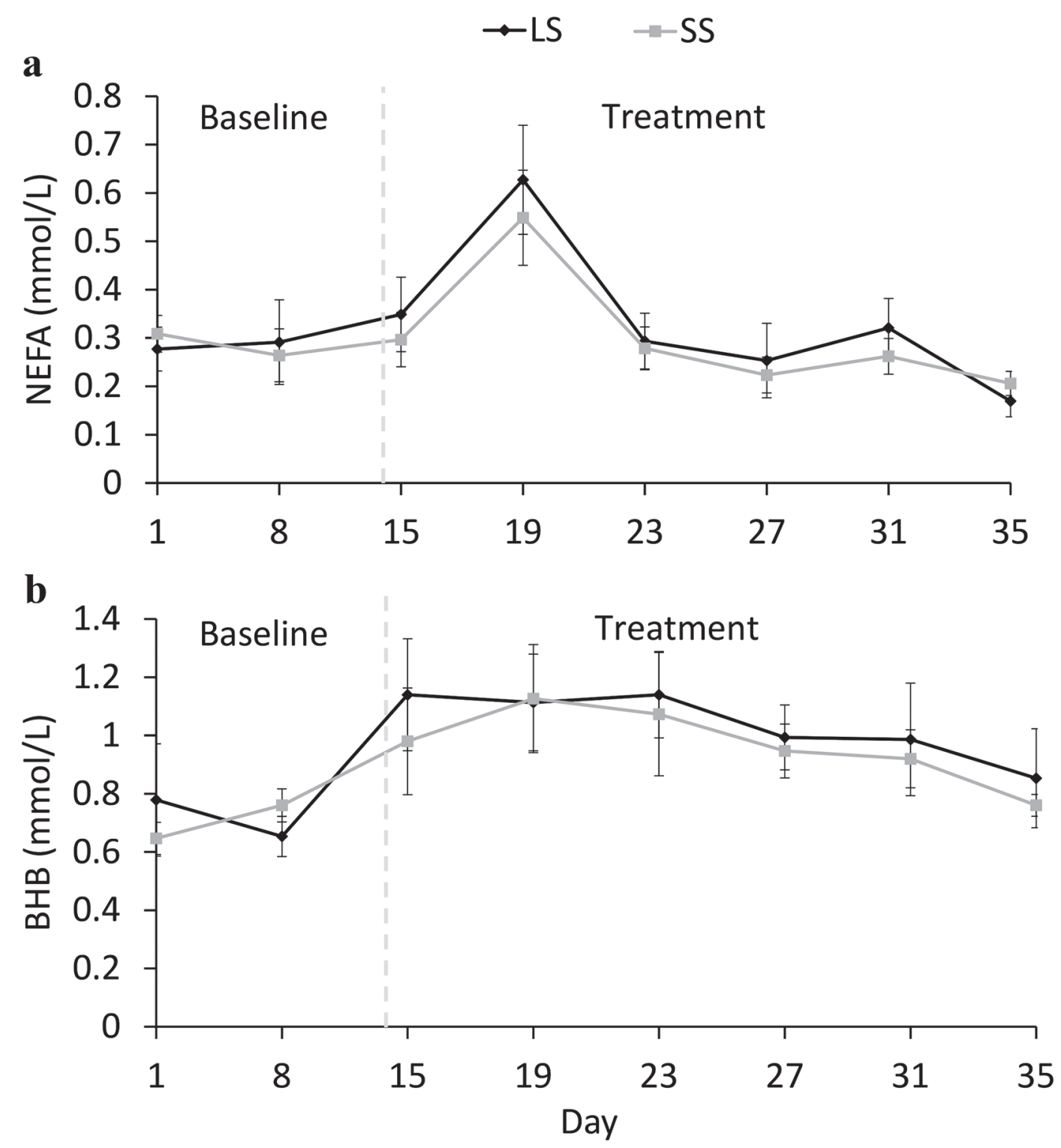

Figure 1. Average $( \pm \mathrm{SE})$ for (a) serum nonesterified fatty acid (NEFA; mmol/L) and (b) BHB (mmol/L) concentrations, for cows fed 1 of 2 dietary treatments $(\mathrm{n}=15$ per treatment) from d 15 to 35 , deficient in energy available for milk production. These 2 dietary treatments were identical in composition (1.58 Mcal $/ \mathrm{kg}$ of $\mathrm{NE}_{\mathrm{L}} ; 73 \%$ forage) differing only in straw chop length (LS = long straw chopped with a 10.16-cm screen; $\mathrm{SS}=$ short straw chopped with a $2.54-\mathrm{cm}$ screen). All cows were fed the same lactating diet (1.66 Mcal $/ \mathrm{kg}$ of $\mathrm{NE}$; $68 \%$ forage) from d 1 to 14 .

Similarly, a treatment by day interaction was detected for the sorting against medium-sized particles: on d 15, 27 , and 34 cows on the LS sorted more against the medium particle fraction than cows on the SS. Furthermore, cows on the LS diet sorted more in favor of the short and fine particles of the diet on all days, except $\mathrm{d}$ 15,25 , and 29 and d 29, 32, and 34, respectively, where sorting for these fractions did not occur.

During the baseline period, no association was detected between feed sorting and serum NEFA concentration. During the experimental period, for cows on the LS diet greater serum NEFA concentration was associated with greater sorting in favor of the short dietary particles $[\%$ short particle sorting $=4.6 \times$ NEFA $(\mathrm{mmol} / \mathrm{L})+101.7 ; \mathrm{R}^{2}=0.28 ; P=0.04 ;$ Figure 2a]. A similar association was detected with SS cows; greater serum NEFA concentration tended to be associated with greater sorting in favor of short dietary particles $[\%$ short particle sorting $=2.8 \times$ NEFA $(\mathrm{mmol} / \mathrm{L})+100.0 ; \mathrm{R}^{2}=0.10 ; P=0.1 ;$ Figure $\left.2 \mathrm{a}\right]$. Furthermore, on the LS diet greater serum NEFA concentration was associated with greater sorting against the longest dietary particles [\% long particle sorting $=-12.8 \times \mathrm{NEFA}(\mathrm{mmol} / \mathrm{L})+93.4 ; \mathrm{R}^{2}=0.26 ; P=$ 
0.05; Figure 2b]. Similarly, on the SS diet, greater serum NEFA concentration tended to be associated with greater sorting against the longest dietary particles [\% long particle sorting $=-13.7 \times \mathrm{NEFA}(\mathrm{mmol} / \mathrm{L})+$ 99.5; $\mathrm{R}^{2}=0.17 ; P=0.1$; Figure $\left.2 \mathrm{~b}\right]$.

Following the 21-d experimental period, cows were placed back onto the baseline diet, where DMI (25.4 $\mathrm{kg} / \mathrm{d} ; \mathrm{SE}=0.77)$ and milk production $(40.3 \mathrm{~kg} / \mathrm{d} ; \mathrm{SE}=$ 0.48 ) returned to similar values to that of the baseline period. Additionally, cows spent $238.3 \pm 12.0 \mathrm{~min} / \mathrm{d}$ eating, ate at a rate of $0.11 \pm 0.0 \mathrm{~kg}$ of $\mathrm{DM} / \mathrm{min}$, and ruminated $572.7 \pm 2.89 \mathrm{~min} / \mathrm{d}$. Last, sorting behavior during this time period was similar to that observed during the initial baseline period (d 1-14) as cows continued to sort against the long fractions $(95.3 \%$; $\mathrm{SE}=$ 1.03), did not sort for or against the medium particles $(100.0 \%$; $\mathrm{SE}=0.10)$, and sorted in favor of the short $(101.4 \%$; $\mathrm{SE}=0.19)$ and fine $(101.2 \% ; \mathrm{SE}=0.28)$ fractions of the diet.

\section{DISCUSSION}

The aim of this study was to determine how feeding behavior of dairy cows is altered in response to a diet-induced period of NEB, and if this response varied depending on dietary particle size distribution. Following the commencement of the experimental diets, where cows consumed a diet in which energy was diluted, DMI dropped by $3.1 \mathrm{~kg} / \mathrm{d}$ for cows on the LS diet and $2.5 \mathrm{~kg} / \mathrm{d}$ for cows on the SS diet. This drop in DMI reduced the energy available for milk production by $\sim 16.4 \%$ for cows on the LS diet and $\sim 14.1 \%$ for cows on the SS diet. These were slightly less than the intended $20 \%$ reduction in energy available for milk production, as the reduction in DMI on the experimental diets was less than predicted, based on the formulation of those diets. Despite reduced DMI, across treatments, cows also spent more time feeding during the experimental period. Cows on LS diet spent $55 \mathrm{~min} / \mathrm{d}$ more time eating than during the baseline period and approximately $29 \mathrm{~min} / \mathrm{d}$ more time eating during the experimental period than cows on the SS diet. Greater time spent eating at a slower rate is expected given the longer straw chop length and the greater degree of feed sorting that cows on the LS diet exhibited. This is supported by previous research where it has been demonstrated that larger particle size is associated with greater eating time of dairy cows (Soita et al., 2000; Alamouti et al., 2014). Furthermore, forages with greater NDF take longer to consume (Yang and Beauchemin, 2006) and greater inclusion rates of roughages in the diet are also associated with greater feeding times (Jiang et al., 2017).

Following the introduction of the experimental diets, both LS and SS cows displayed elevated NEFA and BHB concentrations. Moyes et al. (2009) reported similar increases in NEFA and BHB concentrations following their diet-induced NEB treatment. The increase in NEFA and BHB concentrations reported in the current study were greater compared with research done by Gross et al. (2011), who diet-induced cows into a state of NEB at approximately 100 DIM and reported peaks in NEFA and BHB of $0.27 \mathrm{mmol} / \mathrm{L}$ and $0.64 \mathrm{mmol} / \mathrm{L}$, respectively. The NEFA concentrations of $0.7 \mathrm{mmol} / \mathrm{L}$, or above, are indicative of NEB (Ospina et al., 2010). Further, researchers typically describe BHB values $\geq 1.2$ $\mathrm{mmol} / \mathrm{L}$ as a cut-off point for hyperketonemia (Nielen et al., 1994; Duffield et al., 2009). Throughout the experimental period, approximately $37 \%$ of cows experienced NEFA concentrations $\geq 0.7 \mathrm{mmol} / \mathrm{L}$ and $63 \%$ of cows experienced BHB concentrations $\geq 1.2 \mathrm{mmol} / \mathrm{L}$. Therefore, the elevations in NEFA and BHB concentra-

Table 5. Effect of dietary treatments on the reticulorumen $\mathrm{pH}$ of Holstein dairy cows

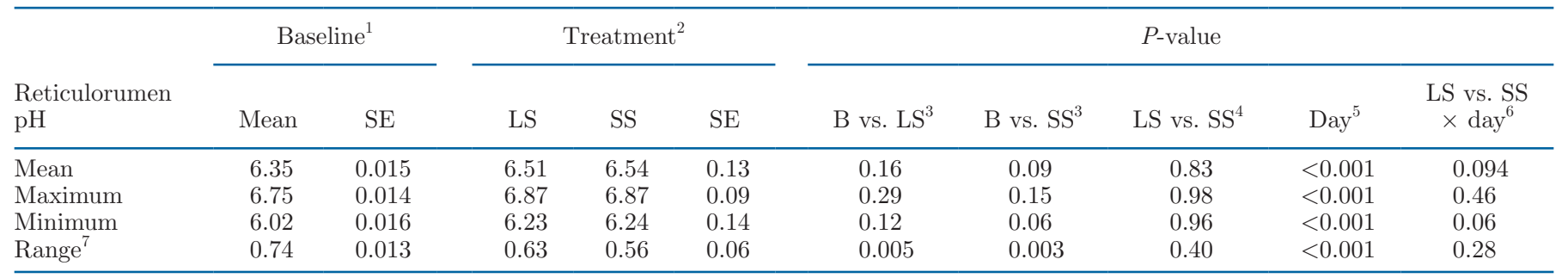

${ }^{1}$ Baseline $=14$-d period following enrollment (1.66 Mcal $/ \mathrm{kg}$ of $\mathrm{NE}_{\mathrm{L}} ; 68 \%$ forage).

${ }^{2} \mathrm{LS}=$ long straw diet (straw chopped with a 10.16-cm screen, $\mathrm{n}=15$ ); $\mathrm{SS}=$ short straw diet (straw chopped with a $2.54-\mathrm{cm}$ screen, $\mathrm{n}=15$ ). Treatment diets $\left(1.58 \mathrm{Mcal} / \mathrm{kg}\right.$ of $\mathrm{NE}_{\mathrm{L}} ; 73 \%$ forage) were fed over a 21-d experimental period, beginning at the start of $\mathrm{d} 15$ to the end of $\mathrm{d} 35$.

${ }^{3}$ Comparison of data, within treatment, from the baseline (B) period to the experimental period.

${ }^{4}$ Comparison of data between treatments (LS vs. SS) within the experimental period.

${ }^{5}$ Day $=$ day effect during the experimental period.

${ }^{6}$ Interaction of treatment (LS vs. SS) and day during the experimental period.

${ }^{7}$ Range $=$ maximum - minimum reticulorumen $\mathrm{pH}$. 


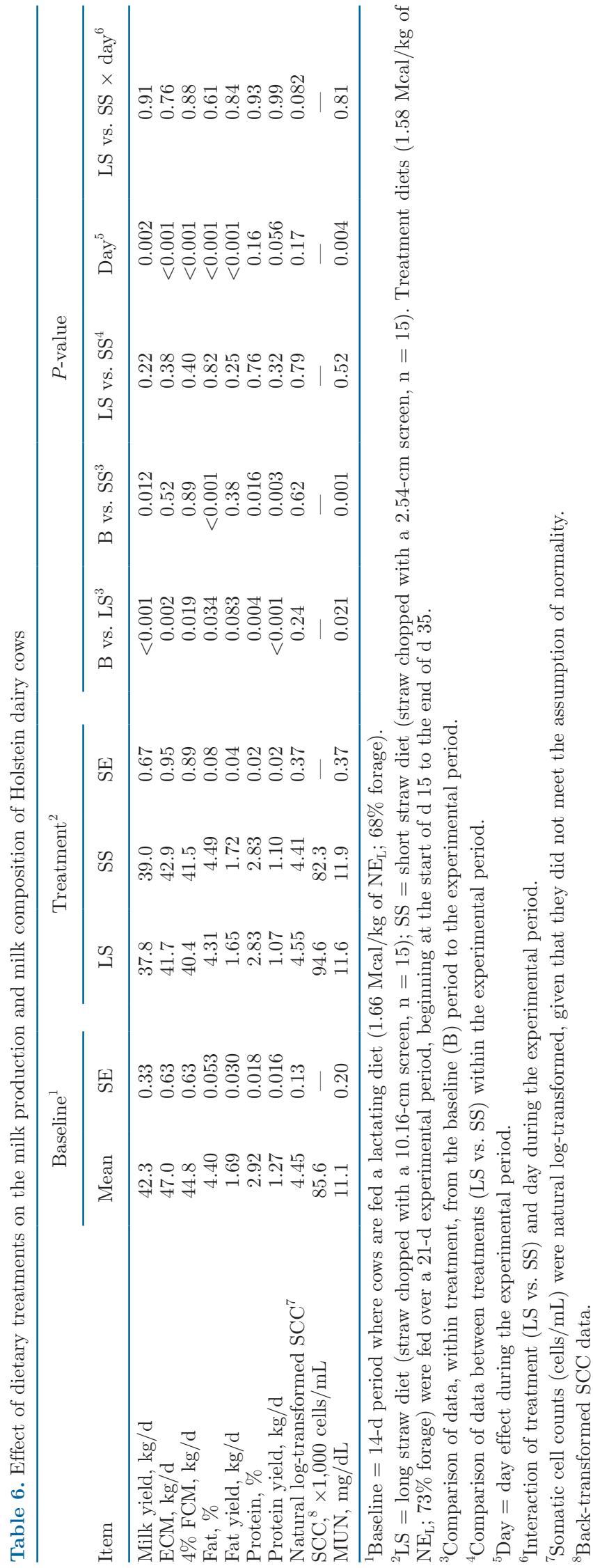

tions in the experimental period, and the percentage of cows exceeding NEFA and BHB thresholds indicative of NEB, indicate that our experimental model was successful in inducing cows into a state of NEB.

Occurrence of diet-induced NEB is further supported by the effects of the experimental diets on milk yield. Across treatments, cows experienced a decrease in milk yield throughout the experimental period compared with their baseline period: milk yield of cows on the LS and SS diets was decreased by 4.5 and $3.3 \mathrm{~kg} / \mathrm{d}$, respectively. A decrease in milk yield was similarly observed in previous studies where NEB was induced through dietary treatments (Moyes et al., 2009; Gross et al., 2011). The decrease in milk yield is related to the drop in DMI, and thus energy intake, observed during this period. Following the dietary change, LS cows consumed $16.4 \%$ less energy for lactation and produced $10.6 \%$ less milk. Similarly, SS cows consumed $14.1 \%$ less energy for lactation and produced $7.8 \%$ less milk compared with the baseline period. However, according to the NRC (2001) requirements, cows were still producing more milk than their dietary nutrient intake allowed for. Based on nutrient intakes, cows should only have produced $\sim 35 \mathrm{~kg} / \mathrm{d}$ of milk; however, cows on the LS diet surpassed this by $\sim 3 \mathrm{~kg} / \mathrm{d}$ and cows on the $\mathrm{SS}$ diet by $\sim 4 \mathrm{k} / \mathrm{d}$. The energy required to maintain the observed levels of milk yield was likely sourced from mobilized body fat during the experimental period, as evidenced by the elevated serum NEFA and blood BHB concentrations.

Throughout the experimental period, cows on the LS and SS diets continued to sort, as they did during the baseline period, for the smaller, more energy-dense components of the diet, while sorting against the longer, less energy-dense components. However, greater differences were seen for cows on the LS diet, as they sorted to a greater degree against the long particle fraction and in favor of the short and fine fractions than cows on the SS diet. This was expected, as in previous research it has been demonstrated that feed sorting will increase with longer forage particle size (Leonardi and Armentano, 2003; Miller-Cushon et al., 2013). Coon et al. (2018) demonstrated that early-lactation cows increased their sorting against the longer fractions of a diet when fed a TMR containing $9 \%$ straw chopped with a 5 -cm screen, compared with those fed a TMR containing the same level of straw chopped with a 2.5cm screen. Similarly, Jiang et al. (2018) established that when cows were fed different forages varying in particle length, sorting activity decreased with reduced forage particle size, regardless of forage type.

The sorting observed on the experimental diets may help explain why milk fat content was decreased for cows on the LS diet, but increased for cows on the 
SS diet. Cows on the LS diet increased their sorting against the longer forage components of the diet compared with cows on the SS diet. Greater milk fat content has been associated in several studies with less sorting against long dietary particles (DeVries et al., 2011; Fish and DeVries, 2012; Miller-Cushon and DeVries, 2017). Cows on the SS diet sorted less and tended to have higher mean reticulorumen $\mathrm{pH}$ values compared with the baseline period and, thus, may have produced milk with greater fat content as a result. Alternatively, cows on the LS diet sorted more against the longer particles and exhibited no significant changes in their mean reticulorumen $\mathrm{pH}$, despite being fed a higher forage diet. Consequently, this may have affected the milk fat content for cows on the LS diet.

Cows on the LS and SS diets produced milk of lesser protein content and yield and had greater MUN concentration during the experimental period compared with their baseline values. The increase in MUN concentration between the baseline and experimental period is likely due to the less energy-dense diets fed during the experimental period. These energy-diluted diets likely limited the rumen microbes from receiving sufficient energy to properly utilize ammonia, causing an increase in MUN concentrations (Huhtanen et al., 2015). Researchers have also previously demonstrated a correlation between the amount of dietary energy and protein content and yield (Cragle et al., 1986). Thus, in situations of energy deficiency, it is common to see a decrease in milk protein percentage. Under periods of severe energy deficiency, decreases in protein yield are also often evident (Thomas, 1980). Therefore, based on the formulation of the experimental diets, a decrease in milk protein content and yield, as well as an increase in MUN concentration was not unexpected.

In support of our hypothesis, a linear association between serum NEFA concentration and feed sorting was detected during the experimental period for both cows on the SS and LS diets. Cows with greater serum NEFA concentration, and therefore experiencing a greater degree of NEB, sorted more in favor of the smaller, more energy-dense components of the diet and less against the longer, less energy-dense fractions. Therefore, as experienced energy deficit increased, the propensity for cows to sort their feed increased concurrently. While we believe the current work to be the first study to evaluate feeding sorting behavior under a state of NEB, other researchers have evaluated how diet selection may change in response to a physiological need. For example, Emmans (1977) demonstrated that growing broiler chickens will select a diet that more closely matches their protein requirements when provided with 2 diets of similar protein content. The idea that animals will select diets to maintain physiological balance is further supported by Kyriazakis and Oldham (1993), who determined that when growing lambs were given access to diets with varying $\mathrm{CP}$ content, lambs were able to select a diet that met their nutrient requirements for $\mathrm{CP}$, while avoiding diets that provided an excess of protein intake.

Thus, previous and current work demonstrates that not only will animals alter their feed selection behavior to meet their metabolic needs, but they will selectively consume diets that promote metabolic homeostasis and satisfy their energy and nutrient requirements. Specifically, the results of the current study support

Table 7. Effect of dietary treatments on the sorting $(\%)^{1}$ behavior of groups of Holstein dairy cows

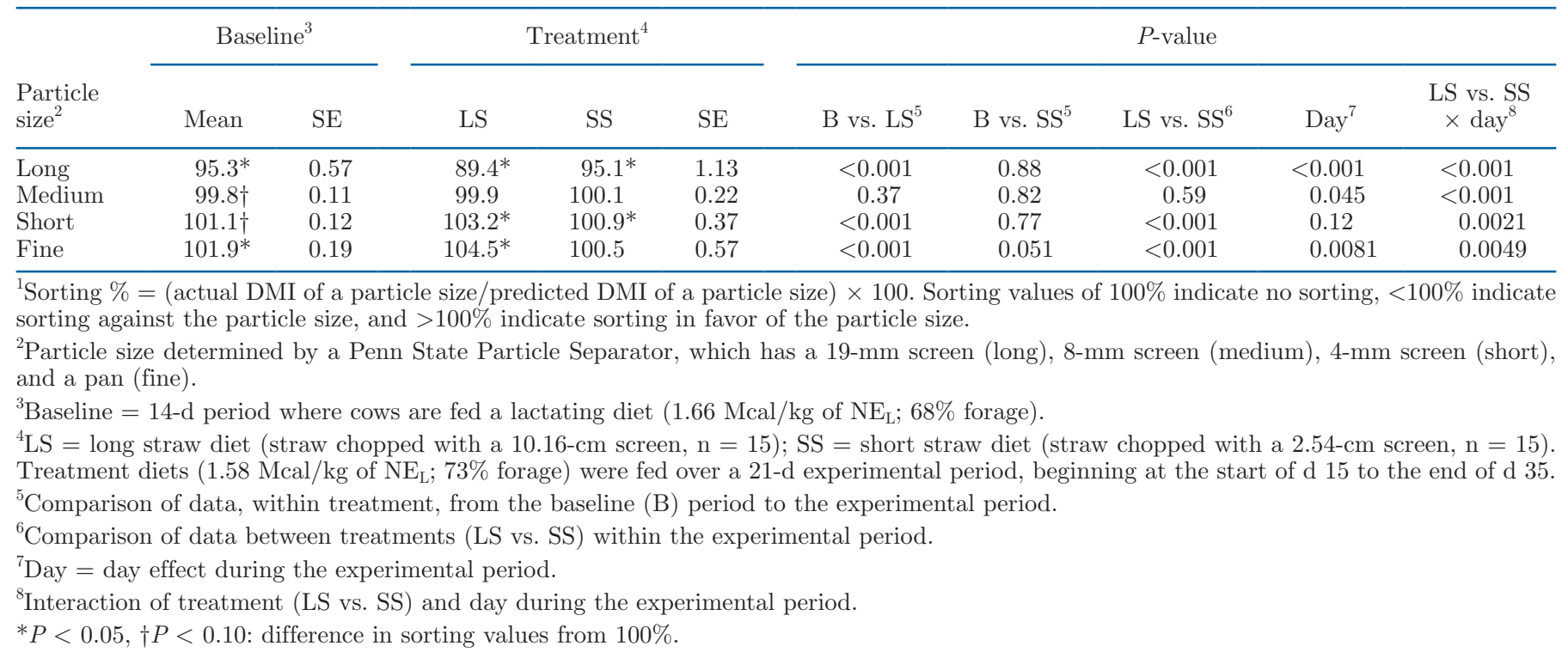


our hypothesis that dairy cows will alter their feed sorting behavior to maximize nutrient consumption when experiencing a state of NEB. All cows will experience NEB to varying degrees and severities in early lactation (Bell, 1995). While we may not be able to completely prevent the incidence of NEB, this research provides insight on ways in which dairy cow may cope with this state in effort to mitigate the degree to which they will experience it. Further research is needed to understand the mechanisms and motivations behind this altered feeding behavior during this inevitable state.

While the present study demonstrates that a dietinduced period of NEB can greatly affect feed sorting behavior, the effect on meal parameters was minimal. The high-forage experimental diets resulted in cows consuming significantly less DM, spending longer durations of time eating, consuming fewer meals, and
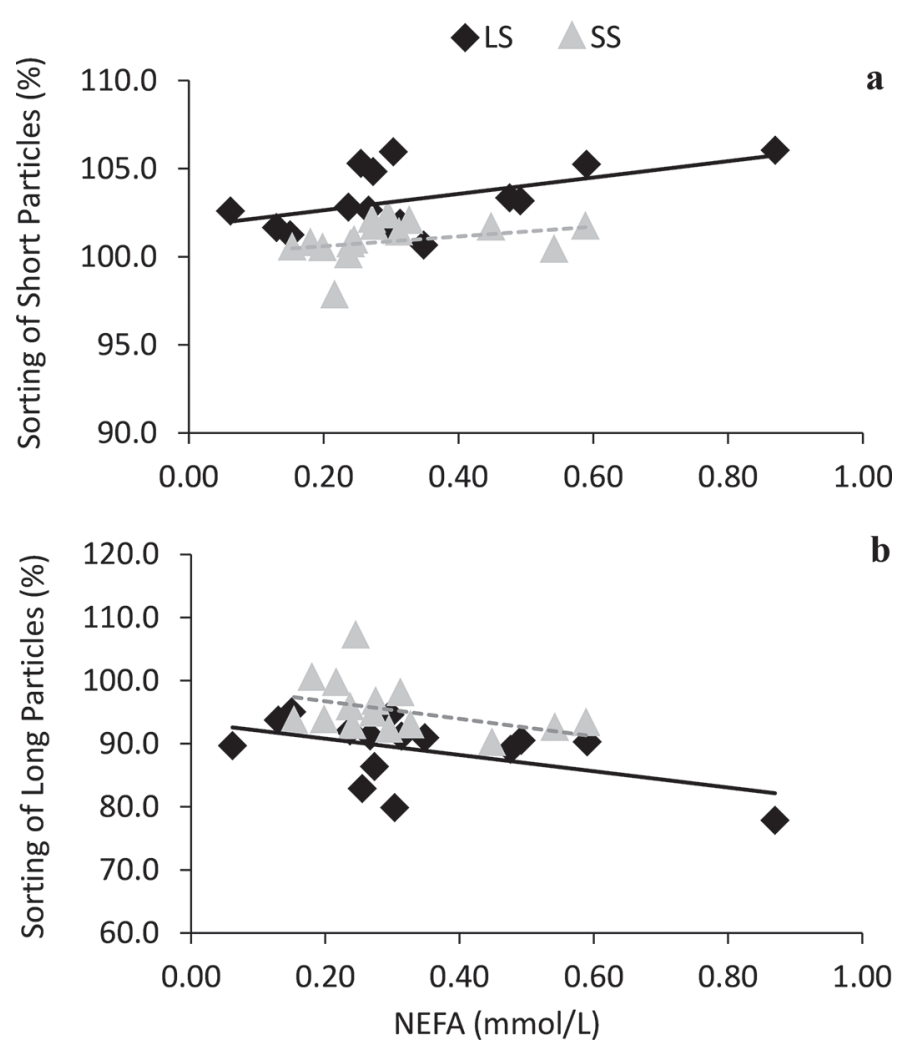

Figure 2. Association of serum nonesterified fatty acid (NEFA) concentration $(\mathrm{mmol} / \mathrm{L})$ and sorting behavior of cows $(\mathrm{n}=15$ per treatment) on long and short straw treatments. These 2 dietary treatments were identical in composition $\left(1.58 \mathrm{Mcal} / \mathrm{kg}\right.$ of $\mathrm{NE}_{\mathrm{L}} ; 73 \%$ forage) and differed only in straw chop length (LS = long straw chopped with a 10.16-cm screen; SS = short straw chopped with a $2.54-\mathrm{cm}$ screen) with (a) sorting in favor of short particles of the diets $(<8,>4 \mathrm{~mm})$ : LS $\left[\%\right.$ short particle sorting $=4.6 \times \mathrm{NEFA}(\mathrm{mmol} / \mathrm{L})+101.7 ; \mathrm{R}^{2}=0.28$ and SS $\left[\%\right.$ short particle sorting $=2.8 \times \mathrm{NEFA}(\mathrm{mmol} / \mathrm{L})+100.0 ; \mathrm{R}^{2}$ $=0.10]$; and (b) sorting against the long particles of the diets $(>19$ $\mathrm{mm})$ : LS [\% long particle sorting $=-12.8 \times \mathrm{NEFA}(\mathrm{mmol} / \mathrm{L})+93.4$; $\left.\mathrm{R}^{2}=0.26\right]$ and SS $[\%$ long particle sorting $=-13.7 \times \mathrm{NEFA}(\mathrm{mmol} / \mathrm{L})$ $\left.+99.5 ; \mathrm{R}^{2}=0.17\right]$.

Journal of Dairy Science Vol. 103 No. 8, 2020 having longer meal times compared with the baseline period. These results are supported by Leonardi and Armentano (2003) and DeVries et al. (2007) who demonstrated that cows fed a higher forage diet will spend more time eating, but consume less DM overall. Furthermore, minutes between each meal, time spent not eating within a meal, the sum of minutes in each meal per day that cows did not spend consuming feed, and meal size ( $\mathrm{kg}$ of DMI per meal) did not differ from the baseline period. In the present study, although cows took longer to eat due to the high forage content (Leonardi and Armentano, 2003; DeVries et al., 2007), cows were still able to consume similar amounts of DM per meal. Thus, it can be concluded that the effects the experimental diets had on meal parameters in the present study were likely a result of the higher forage inclusion rates in those experimental diets, and not a result of the diet-induced NEB the cows experienced during exposure to those diets.

\section{CONCLUSIONS}

Lactating dairy cows, at peak lactation, in this study were successfully diet-induced into a period of NEB by switching them from their lactation diet to 1 of 2 experimental diets with high straw and decreased energy density that varied in particle size and limited nutrient intake. On those diets, cows spent more time eating, ate slower, and consumed fewer meals compared with the baseline period. Also, on those diets, cow sorted in favor of the smaller, more energy-dense particles within the diet, while sorting against the longest, less energydense particles. Greater sorting was observed for those cows who were fed the experimental diet with longer straw particle size. Cows with greater serum NEFA concentration during the experimental period sorted to a greater degree in favor of the smaller, more energydense components of the diet and to a greater degree against the longer, less energy-dense components of the diet. Overall, these results indicate that when experiencing a state of NEB, cows may not only alter their feed selection behavior in attempt to consume greater amounts of dietary energy, but also the extent to which they alter their behavior may be directly correlated with the severity of NEB they are experiencing.

\section{ACKNOWLEDGMENTS}

The authors thank the staff of the University of Guelph, Elora Research Station-Dairy Facility (Elora, ON, Canada) for their assistance in facilitating this research project. Special thanks go to Robin Crossley, Kaitlyn Dancy, Meagan King, Sarah Parsons, and Casey Havekes of the University of Guelph (Guelph, ON, 
Canada) for their assistance with data collection. This project was financially supported by a Natural Sciences and Engineering Research Council of Canada (Ottawa, ON, Canada) Discovery Grant. Further, equipment for this project was supported through contributions from the Canadian Foundation for Innovation (Ottawa, ON, Canada) and the Ontario Research Fund (Toronto, ON, Canada). The authors have not stated any conflicts of interest.

\section{REFERENCES}

Alamouti, A. A., M. Alikhani, G. R. Ghorbani, A. Teimouri-Yansari, and M. Bagheri. 2014. Response of early-lactation Holstein cows to partial replacement of neutral detergent soluble fibre for starch in diets varying in forage particle size. Livest. Sci. 160:60-68. https:/ /doi.org/10.1016/j.livsci.2013.12.009.

AOAC International. 2000. Official Methods of Analysis. 17th ed. AOAC International, Arlington, VA.

Azizi, O., O. Kaufmann, and L. Hasselmann. 2009. Relationship between feeding behavior and feed intake of dairy cows depending on their parity and milk yield. Livest. Sci. 122:156-161. https://doi .org/10.1016/j.livsci.2008.08.009.

Beauchemin, K. A., and W. Z. Yang. 2005. Effects of physically effective fiber on intake, chewing activity, and ruminal acidosis for dairy cows fed diets based on corn silage. J. Dairy Sci. 88:21172129. https://doi.org/10.3168/jds.S0022-0302(05)72888-5.

Bell, A. W. 1995. Regulation of organic nutrient metabolism during transition from late pregnancy to early lactation. J. Anim. Sci. 73:2804-2819. https://doi.org/10.2527/1995.7392804x.

CCAC. 2009. Guidelines on: The care and use of farm animals in research, teaching and testing. Canadian Council on Animal Care, Ottawa, ON, Canada.

Chapinal, N., D. M. Veira, D. M. Weary, and M. A. G. von Keyserlingk. 2007. Technical note: Validation of a system for monitoring individual feeding and drinking behavior and intake in group-housed cattle. J. Dairy Sci. 90:5732-5736. https://doi.org/ 10.3168/jds.2007-0331.

Coon, R. E., T. F. Duffield, and T. J. DeVries. 2018. Effect of straw particle size on the behavior, health, and production of early-lactation dairy cows. J. Dairy Sci. 101:6375-6387. https://doi.org/10 $.3168 /$ jds.2017-13920.

Cragle, R. G., M. R. Murphy, S. W. Williams, and J. H. Clark. 1986. Effects of altering milk production and composition by feeding on multiple component milk pricing system. J. Dairy Sci. 69:282-289. https://doi.org/10.3168/jds.S0022-0302(86)80399-X.

DeVries, T. J., K. A. Beauchemin, and M. A. G. von Keyserlingk. 2007. Dietary forage concentration affects the feed sorting behavior of lactating dairy cows. J. Dairy Sci. 90:5572-5579. https://doi .org/10.3168/jds.2007-0370.

DeVries, T. J., F. Dohme, and K. A. Beauchemin. 2008. Repeated ruminal acidosis challenges in lactating dairy cows at high and low risk for developing acidosis: feed sorting. J. Dairy Sci. 91:3958 3967. https://doi.org/10.3168/jds.2008-1347.

DeVries, T. J., and R. M. Gill. 2012. Adding liquid feed to a total mixed ration reduces feed sorting behavior and improves productivity of lactating dairy cows. J. Dairy Sci. 95:2648-2655. https:// doi.org/10.3168/jds.2011-4965.

DeVries, T. J., L. Holtshausen, M. Oba, and K. A. Beauchemin. 2011. Effect of parity and stage of lactation on feed sorting behavior of lactating dairy cows. J. Dairy Sci. 94:4039-4045. https://doi.org/ 10.3168/jds.2011-4264.

DeVries, T. J., M. A. G. von Keyserlingk, D. M. Weary, and K. A. Beauchemin. 2003. Measuring the feeding behavior of lactating dairy cows in early to peak lactation. J. Dairy Sci. 86:3354-3361. https://doi.org/10.3168/jds.S0022-0302(03)73938-1.

Duffield, T. F., K. D. Lissemore, B. W. McBride, and K. E. Leslie. 2009. Impact of hyperketonemia in early lactation dairy cows on health and production. J. Dairy Sci. 92:571-580. https://doi.org/ 10.3168/jds.2008-1507.

Emmans, G. C. 1977. The nutrient intake of laying hens given a choice of diets in relation to their production requirements. Br. Poult. Sci. 18:227-236. https://doi.org/10.1080/00071667708416358.

Falk, M., A. Münger, and F. Dohme-Meier. 2016. Technical note: A comparison of reticular and ruminal $\mathrm{pH}$ monitored continuously with 2 measurement systems at different weeks of early lactation. J. Dairy Sci. 99:1951-1955. https://doi.org/10.3168/jds.2015-9725.

Ferraretto, L. F., H. Gencoglu, K. S. Hackbart, A. B. Nascimento, F. Dalla Costa, R. W. Bender, J. N. Guenther, R. D. Shaver, and M. C. Wiltbank. 2014. Effect of feed restriction on reproductive and metabolic hormones in dairy cows. J. Dairy Sci. 97:754-763. https: //doi.org/10.3168/jds.2013-6925.

Fish, J. A., and T. J. DeVries. 2012. Short communication: Varying dietary dry matter concentration through water addition: Effect on nutrient intake and sorting of dairy cows in late lactation. J. Dairy Sci. 95:850-855. https://doi.org/10.3168/jds.2011-4509.

Goff, J. P., and R. L. Horst. 1997. Physiological changes at parturition and their relationship to metabolic disorders. J. Dairy Sci. 80:1260-1268. https://doi.org/10.3168/jds.S0022-0302(97)76055 $-7$.

Grant, R. J., and L. F. Ferraretto. 2018. Silage review: silage feeding management: silage characteristics and dairy cow feeding behavior. J. Dairy Sci. 101:4111-4121. https://doi.org/10.3168/jds.2017 -13729 .

Gross, J., H. A. van Dorland, R. M. Bruckmaier, and F. J. Schwarz. 2011. Performance and metabolic profile of dairy cows during a lactational and deliberately induced negative energy balance with subsequent realimentation. J. Dairy Sci. 94:1820-1830. https://doi .org/10.3168/jds.2010-3707.

Heinrichs, A. J. 2013. The Penn State Particle Separator. Extension publication DSE 2013-186. Pennsylvania State University, College Park

Huhtanen, P., E. H. Cabezas-Garcia, S. J. Krizsan, and K. J. Shingfield. 2015. Evaluation of between-cow variation milk urea and rumen ammonia nitrogen concentrations and the association with nitrogen utilization and diet digestibility in lactating cows. J. Dairy Sci. 98:3182-3196. https://doi.org/10.3168/jds.2014-8215.

Jiang. F. G., X. Y. Lin, Z. G. Yan, Z. Y. Hu, G. M. Liu, Y. D. Sun X. W. Liu, and Z. H. Wang. 2017. Effect of dietary roughage level on chewing activity, ruminal $\mathrm{pH}$, and saliva secretion in lactating Holstein cows. J. Dairy Sci. 100:2660-2671. https://doi.org/10 $.3168 /$ jds.2016-11559.

Jiang, F. G., X. Y. Lin, Z. G. Yan, Z. Y. Hu, Y. Wang, and Z. H. Wang. 2018. Effect of forage source and particle size on feed sorting, milk production and nutrient digestibility in lactating dairy cows. J. Anim. Physiol. Anim. Nutr. (Berl.) 102:1472-1481. https: //doi.org/10.1111/jpn.12984.

Kanz, P., M. Drillich, D. Klein-Jöbstl, B. Mair, S. Borchardt, L. Meyer, I. Schwendenwein, and M. Iwersen. 2015. Suitability of capillary blood obtained by a minimally invasive lancet technique to detect subclinical ketosis in dairy cows by using 3 different electronic hand-held devices. J. Dairy Sci. 98:6108-6118. https://doi .org/10.3168/jds.2014-8957.

King, M. T. M., R. E. Crossley, and T. J. DeVries. 2016. Synchronization of dairy cows does not limit the behavioral response to treatment in mixed treatment experimental designs. Front. Vet. Sci. 3:98. https://doi.org/10.3389/fvets.2016.00098.

Kyriazakis, I., and J. D. Oldham. 1993. Diet selection in sheep: The ability of growing lambs to select a diet that meets their crude protein requirements. Br. J. Nutr. 69:617-629. https://doi.org/10 $.1079 /$ BJN19930064.

Leonardi, C., and L. E. Armentano. 2003. Effect of quantity, quality, and length of alfalfa hay on selective consumption by dairy cows. J. Dairy Sci. 86:557-564. https://doi.org/10.3168/jds.S0022 $-0302(03) 73634-0$

MacDonald, P. D. M., and P. E. J. Green. 1988. User's Guide to Program MIX: An Interactive Program for Fitting Mixtures of Distributions. Release 2.3, January 1988. Ichthus Data Systems, Hamilton, Ontario, Canada. 
Maulfair, D. D., and A. J. Heinrichs. 2013. Effects of varying forage particle size and fermentable carbohydrates on feed sorting, ruminal fermentation, and milk and component yields of dairy cows. J. Dairy Sci. 96:3085-3097. https://doi.org/10.3168/jds.2012-6048.

McArt, J. A., D. V. Nydam, and G. R. Oetzel. 2012. Epidemiology of subclinical ketosis in early lactation dairy cattle. J. Dairy Sci. 95:5056-5066. https://doi.org/10.3168/jds.2012-5443.

Miller-Cushon, E. K., and T. J. DeVries. 2017. Associations between feed push-up frequency, feeding and lying behavior and milk yield composition of dairy cows. J. Dairy Sci. 100:2213-2218. https:// doi.org/10.3168/jds.2016-12004.

Miller-Cushon, E. K., C. Montoro, A. Bach, and T. J. DeVries. 2013. Effect of early exposure to mixed rations differing in forage particle size on feed sorting of dairy calves. J. Dairy Sci. 96:3257-3264. https://doi.org/10.3168/jds.2012-6415.

Morris, T. R. 1999. Experimental design and analysis in animal sciences. CABI Publishing, New York, NY.

Moyes, K. M., J. K. Drackley, J. L. Salak-Johnson, D. E. Morin, J. C. Hope, and J. J. Loor. 2009. Dietary-induced negative energy balance has minimal effects on innate immunity during a streptococcus uberis mastitis challenge in dairy cows during mid-lactation. J. Dairy Sci. 92:4301-4316. https://doi.org/10.3168/jds.2009-2170.

National Research Council. 2001. Nutrient Requirements of Dairy Cattle. 7th rev. ed. Natl. Acad. Press, Washington, DC.

Nielen, M., M. G. A. Aarts, G. M. Ad, T. Jonkers, Y. H. Wensing, and Y. H. Schukken. 1994. Evaluation of two cow side tests for the detection of subclinical ketosis in dairy cows. Can. Vet. J. 35:229-232.

Ospina, P. A., D. Nydam, T. Stokol, and T. R. Overton. 2010. Evaluation of nonesterfied fatty acids and beta-hydroxybutyrate in transition dairy cattle in the northeastern United States: critical thresholds for prediction of clinical diseases. J. Dairy Sci. 93:546554. https://doi.org/10.3168/jds.2009-2277.

Perkins, K. H., M. J. VandeHaar, J. L. Burton, J. S. Liesman, R. J. Erskine, and T. H. Elsasser. 2002. Clinical responses to intramammary endotoxin infusions in dairy cows subjected to feed restriction. J. Dairy Sci. 85:1724-1731. https://doi.org/10.3168/jds .S0022-0302(02)74246-X.

SAS Institute Inc. 2013. SAS version 9.4. SAS Institute Inc., Cary, NC.

Schirmann, K., M. A. G. von Keyserlingk, D. M. Weary, D. M. Veira, and W. Heuweiser. 2009. Technical note: Validation of a system for monitoring rumination in dairy cows. J. Dairy Sci. 92:6052-6055. https://doi.org/10.3168/jds.2009-2361.

Soita, H. W., D. A. Christensen, and J. J. McKinnon. 2000. Influence of particle size on the effectiveness of the fiber in barley silage.
J. Dairy Sci. 83:2295-2300. https://doi.org/10.3168/jds.S0022 -0302(00)75116-2.

Suthar, V. S., J. Canelas-Raposo, A. Deniz, and W. Heuwieser. 2013. Prevalence of subclinical ketosis and relationships with postpartum diseases in European dairy cows. J. Dairy Sci. 96:2925-2938. https://doi.org/10.3168/jds.2012-6035.

Thomas, P. C. 1980. Influence of nutrition on the yield and content of protein in milk. Dietary protein and energy supply. Int. Dairy Fed. Bull. Doc. 125:142.

Tolkamp, B. J., R. J. Dewhurst, N. C. Friggens, I. Kyriazakis, R. F. Veerkamp, and J. D. Oldham. 1998. Diet choice by dairy cows. 1. Selection of feed protein content during the first half of lactation. J. Dairy Sci. 81:2657-2669. https://doi.org/10.3168/jds.S0022 -0302(98)75823-0.

Tyrrell, H. F., and J. T. Reid. 1965. Prediction of the energy value of cow's milk. J. Dairy Sci. 48:1215-1223. https://doi.org/10.3168/ jds.S0022-0302(65)88430-2.

van Hoeij, R. J., J. Dijkstra, R. M. Bruckmaier, J. J. Gross, T. J. G. M. Lam, G. J. Remmelink, B. Kemp, and A. T. M. van Knegsel 2017. The effect of dry period length and postpartum level of concentrate on milk production, energy balance, and plasma metabolites of dairy cows across the dry period and in early lactation. J. Dairy Sci. 100:5863-5879. https://doi.org/10.3168/jds.2016-11703.

Van Soest, P. J., J. B. Robertson, and B. A. Lewis. 1991. Methods for dietary fiber, neutral detergent fiber, and nonstarch polysaccharides in relation to animal nutrition. J. Dairy Sci. 74:3583-3597. https://doi.org/10.3168/jds.S0022-0302(91)78551-2.

Walsh, R. B., J. S. Walton, D. F. Kelton, S. J. LeBlanc, K. E. Leslie, and T. F. Duffield. 2007. The effect of subclinical ketosis in early lactation on reproductive performance of postpartum dairy cows. J. Dairy Sci. 90:2788-2796. https://doi.org/10.3168/jds.2006-560.

Wildman, E. E., G. M. Jones, P. E. Wagner, R. L. Boman, H. F. Troutt Jr., and T. N. Lesch. 1982. A dairy body condition scoring system and its relationship to selected production characteristics. J. Dairy Sci. 65:495-501. https://doi.org/10.3168/jds.S0022 $-0302(82) 82223-6$

Yang, W. Z., and K. A. Beauchemin. 2006. Effects of physically effective fiber on chewing activity and ruminal $\mathrm{pH}$ of dairy cows fed diets based on barley silage. J. Dairy Sci. 89:217-228. https://doi .org/10.3168/jds.S0022-0302(06)72086-0.

\section{ORCIDS}

T. J. DeVries @ https://orcid.org/0000-0001-9364-2456 